\title{
Article \\ Spray Analysis and Combustion Assessment of Diesel-LPG Fuel Blends in Compression Ignition Engine
}

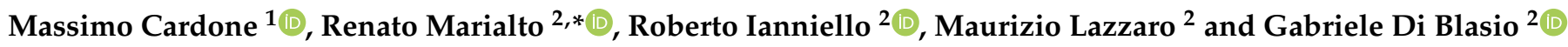 \\ 1 Department of Chemical, Materials and Production Engineering, University of Naples Federico II, \\ via Claudio, 21, 80125 Naples, Italy; massimo.cardone@unina.it \\ 2 CNR-STEMS, Viale Marconi, 4, 80125 Naples, Italy; r.ianniello@im.cnr.it (R.I.); m.lazzaro@im.cnr.it (M.L.); \\ gabriele.diblasio@cnr.it (G.D.B.) \\ * Correspondence: r.marialto@im.cnr.it; Tel.: +39-081-7177185
}

Citation: Cardone, M.; Marialto, R.; Ianniello, R.; Lazzaro, M.; Di Blasio, G. Spray Analysis and Combustion Assessment of Diesel-LPG Fuel Blends in Compression Ignition Engine. Fuels 2021, 2,1-15. https:// doi.org/10.3390/fuels2010001

Received: 6 November 2020 Accepted: 28 December 2020 Published: 31 December 2020

Publisher's Note: MDPI stays neutral with regard to jurisdictional clai$\mathrm{ms}$ in published maps and institutional affiliations.

Copyright: (C) 2020 by the authors. Licensee MDPI, Basel, Switzerland. This article is an open access article distributed under the terms and conditions of the Creative Commons Attribution (CC BY) license (https:// creativecommons.org/licenses/by/ $4.0 /)$.

\begin{abstract}
A major challenge for internal combustion engines (ICEs), and diesel engines, in particular, is the reduction of exhaust emissions, essentially nitrogen oxides (NOx) and particulate matter (PM). In this regard, the potential of LPG-diesel blends was evaluated in this work. The LPG and diesel blends were externally prepared by exploiting their perfect miscibility at high pressures. Two dieselLPG mixtures with $20 \%$ and $35 \%$ by mass LPG concentrations were tested. In terms of spatial and temporal evolution, the spray characterization was performed for the two blends and pure diesel fuel through high-speed imaging technique. The combustion behavior, engine performance and exhaust emissions of LPG-diesel blends were evaluated through a test campaign carried out on a singlecylinder diesel engine. Diesel/LPG sprays penetrate less than pure diesel. This behavior results from a lower momentum, surface tension and viscosity, of the blend jets in comparison to diesel which guarantee greater atomization. The addition of LPG to diesel tends to proportionally increase the spray cone angle, due to the stronger turbulent flow interaction caused by, the lower density and low flash-boiling point. Because of improved atomization and mixing during the injection phase, the blends have shown great potential in reducing PM emissions, without affecting engine performance ( $\mathrm{CO}_{2}$ emissions). The addition of LPG resulted in a significant smoke reduction (about 95\%) with similar NOx emissions and acceptable THC and CO emissions. Furthermore, the low cetane number $(\mathrm{CN})$ and high low-heating value (LHV) ensuring leaner air-fuel mixture, and improvements in terms of efficiency, particularly for a blend with a higher concentration of LPG.
\end{abstract}

Keywords: alternative fuel blends; low-soot; high-efficiency; CI engine; LPG-Diesel blends; Diesel additives

\section{Introduction}

Any combustion process strongly depends on the fuel properties, as are emissions, which directly impact the environment. As for internal combustion engines, increasingly stringent emission regulations have forced the automotive industry to seek innovative and efficient technologies. In particular, for compression ignition (CI) engines, the goal is to reduce the NOx-soot trade-off. Several technologies are being developed on a diesel engine, thanks to the favorable thermodynamics and mechanics, to improve the trade-off further, also taking into account $\mathrm{CO}_{2}$ emissions. However, the study of the combustion system still represents the main cornerstone. As is known, up to 2015 the optimization of piston bowl [1], intake ports, EGR, turbocharger [2] and fuel injection system [3] was mainly directed to increase performance [4], reaching important milestones. Nowadays, researchers and OEM companies, are working hard on the development of new fuel and combustion concepts capable of improving both efficiency, performance and emissions. To this end, new combustion concepts and hardware for compression ignition engines are developed. This scenario also includes powering engines with Liquefied Petroleum Gas 
(LPG)-diesel blends, thus exploiting the potential of such fuel, such as high efficiency and low emission values of nitrogen oxides (NOx) and particulate matter (PM) [5].

This new concept consists of the injection of the LPG-diesel blend (external mixture formation) directly into the combustion chamber during the engine cycle's high-pressure phase. The flame ignition is triggered by the higher reactive diesel fuel [6]. LPG has justified thanks to the high volatility and low reactivity (cetane number, $\mathrm{CN}$ ), which are valuable characteristics that allow a leaner mixture formation compared to the conventional diesel combustion.

Studies performed on LPG-diesel blends have generally found a reduction of soot and NOx emissions. DH Qi et al. [7] demonstrated that this technique provides more significant control of NOx and particulate emissions on existing diesel engines by making simple fuel system changes. Also, Donghui et al. [8] using an LPG / diesel blend observed longer ignition delays, resulting in better air-fuel mixing and reduced soot emissions, but a worsening efficiency and $\mathrm{HC}$ emissions. J Cao et al. [9] conducted engine and spray tests using the blends with different LPG percentages. Regarding the engine tests, the results are aligned with what has already been described above. Regarding the spray characterization, improved fuel atomization was observed, with a reduction in the Sauter Mean Diameter (SMD). It demonstrates, as noted above, how fuel characteristics affect engine performance and emissions [10].

Therefore, the combustion process depends significantly on spray characteristics. Since the LPG is mixed with the diesel, the fuel atomization will no longer rely only on the liquid bulk disintegration and the evaporation and coalescence of the droplets. These phenomena cause a considerable decrease in both the average number of droplets and a different redistribution [11]. Therefore, the use of mixed blends, with miscible fuels characterized by different thermodynamic properties, is of practical and fundamental importance [12,13].

The use of natural gas mixed with diesel is a valid alternative to LPG [14]. However, LPG can provide more flexibility for practical automotive applications as it is easier to manage in terms of storage and it can be stored in a liquid state at a pressure relatively lower than that of natural gas [15]. Furthermore, it guarantees a cooling effect of the combustion chamber thanks to evaporation's latent heat, which allows to increase the power and decrease the exhaust emissions [16]. However, there are still many technical issues to be addressed in applying LPG to a compressed-ignition light-duty engine, starting with the correct and safe management of the right LPG-diesel ratio.

The activity is part of a broader research topic aiming to use the LPG-Diesel mixture in a CI engine through the conventional injection system adaptation with few modifications. This study's main purpose is to evaluate the real potential of this new concept and its applicability on state-of-art engines. With its methodology and analysis conducted, the present study aims to cover the information and the scientific gap with what is present in the literature. There are no or very few results that characterize this new fuel concept in real operating conditions. Additionally, it is worth highlighting the originality of the method adopted and the potential in using LPG as an additive in diesel fuel. Based on the preliminary analysis on the use of LPG/Diesel blends $[17,18]$, the present work focuses on studying the fuel-engine interaction to evaluate the effects of blends on engine outputs, with particular attention to the combustion process and pollutant emissions.

Two diesel-LPG mixtures with $20 \%$ and $35 \%$ by mass LPG concentrations were tested, named "DLPG20" and "DLPG35" respectively. Extensive engine tests were carried out through a single-cylinder engine (SCE). The effect of adding LPG on spray development was also investigated in a quiescent chamber through high-speed shadowgraph imaging. In particular, the information obtained from the spray characterization supports the tests on the single-cylinder, as they provide fundamental information on the spray quality, which strongly affects combustion and emissions. 


\section{Materials and Methods}

\subsection{Single Cylinder Engine}

The new fueling concept was tested on a single-cylinder CI engine [19] derived from a multi-cylinder engine whose cylinder head has been suitably modified. The boundary conditions (intake, exhaust and cooling) are controlled independently of the engine operating point, allowing complete flexibility. The systems are managed through a home-developed control and acquisition system based on LabVIEW, which collects all test cell sensors' low-frequency signals. The test cell layout is shown in Figure 1.

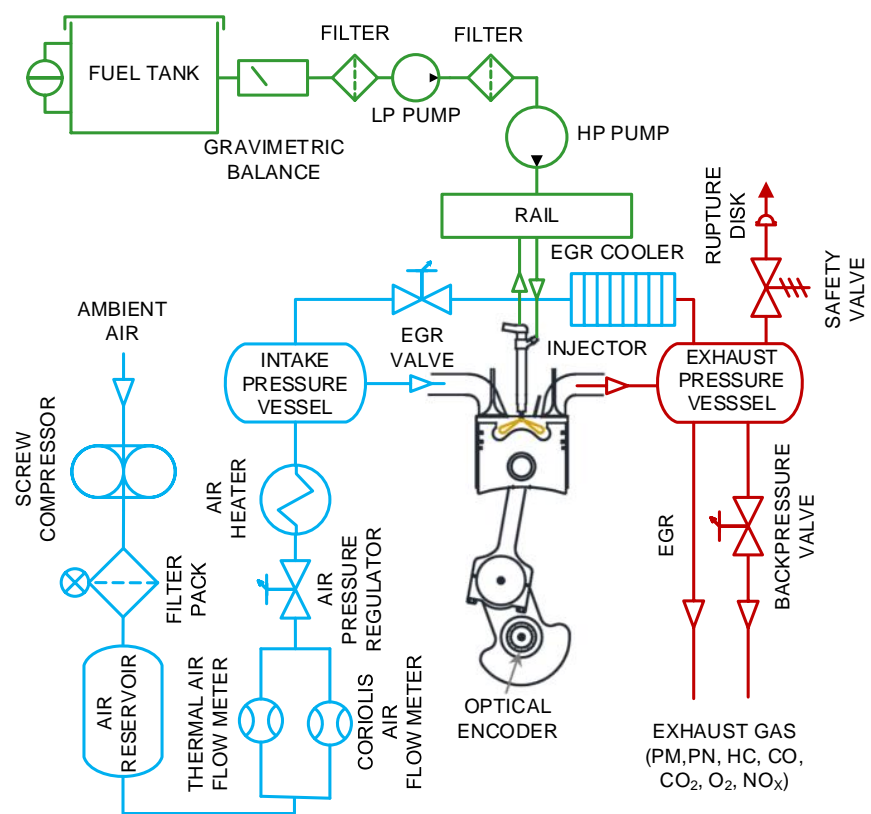

Figure 1. SCE test cell layout.

Also, the calibration settings (EGR level, energizing timing and number of the pulses, swirl ratio) are managed by an open-loop Electronic Control Unit (ECU) [18]. A Kistler piezo-electric pressure transducer was employed to record the in-cylinder pressure by an AVL Indimicro indicating system, which process in real-time the net HRR [10]. The gaseous emissions were measured using an AVL CEBII integrated emissions test bench, while an AVL 415S smoke meter measured the soot concentration. The engine characteristics are listed in Table 1. The fuel flow rate was calculated from the measured $\mathrm{CO}_{2}$ concentration using the carbon balance method [20] validated by the results obtained through an AVL 733 mass flow meter, employed for only diesel tests.

Table 1. SCE and injector characteristics.

Displaced volume $\left[\mathrm{cm}^{3}\right]$
Stroke $\times$ Bore $[\mathrm{mm}]$
Geometrical CR [-]
Max rail pressure [-]
Injector type
Number of holes
Hole Diameter
Cone angle
Rated flow @ 100 bar

477

$90.4 \times 82$

16.5:1

1800 bar

Solenoid 7

$0.141 \mathrm{~mm}$ $148^{\circ}$ $440 \mathrm{~cm}^{3} / 30 \mathrm{~s}$

\subsection{Optical Setup}

In terms of spatial and temporal evolution, the spray characterisation was performed in a test bench suitably designed to perform tests in evaporating conditions. The experi- 
mental setup is schematically illustrated in Figure 2 . The fuel spray was injected into a low velocity and heated air crossflow in a $100 \mathrm{~mm}$ square duct.

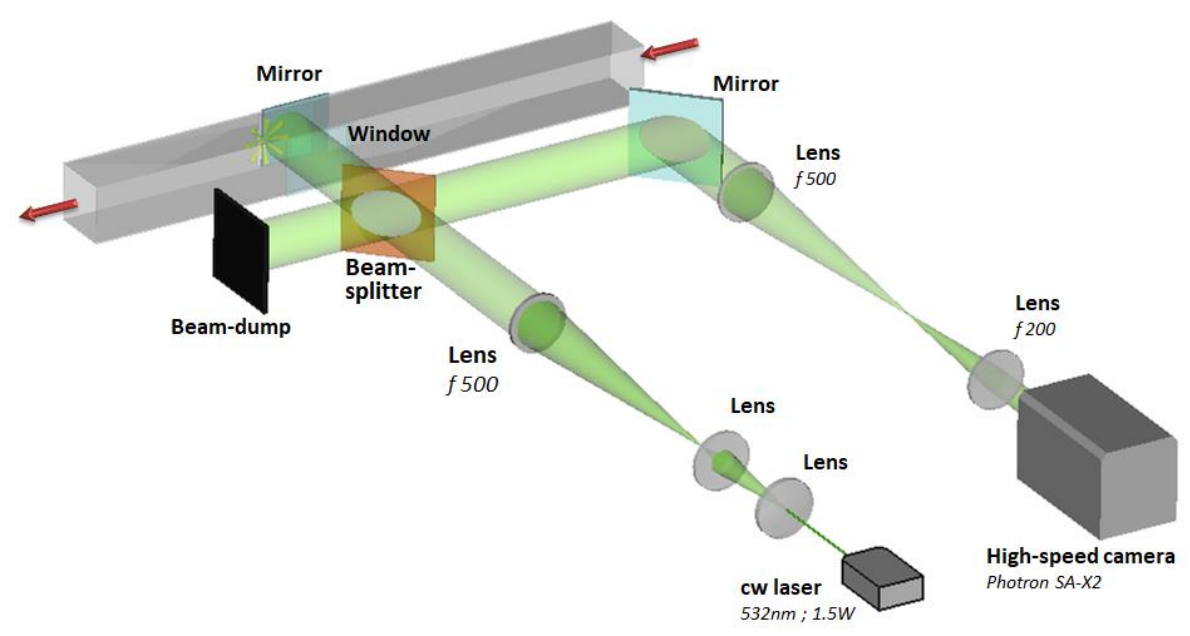

Figure 2. Optical setup.

The spray development was characterized by high-speed shadowgraph imaging. A double-pass shadowgraph layout was made by simply removing the knife-edge in an in-line lens-type schlieren setup. The light source was a cw Nd: YAG laser (532 nm, $1.5 \mathrm{~W})$. The in-line optical setup was made using two plano-convex lenses $500 \mathrm{~mm}$ focal length and $100 \mathrm{~mm}$ diameter. The spray evolution sequences were acquired at 50,000 fps using a high-speed camera (Photron FASTCAM SA-X2 type $1000 \mathrm{k}-\mathrm{M} 2$ ). The image resolution was $0.184 \mathrm{~mm} / \mathrm{pixel}$, and the exposure time was $0.29 \mu \mathrm{s}$. A 7 holes solenoid injector has been employed, whose characteristics are shown in Table 1.

\subsection{Testing Methodology}

The tests campaigns were performed to provide additional information when using LPG-diesel blends and assess the optimal L.P.G./diesel mass ratio. The tested points, listed in Table 2, were performed in steady-state conditions at fixed engine speed (2000 rpm) and varying the engine load conditions, using the reference multi-cylinder engine calibration. Also, the pumping losses, intake, and back-pressure parameters were set to simulate the turbocharger's operating point. The test points performed were extensively used in past activities as reference points as characteristic points of the New European Driving Cycle (NEDC) and World Harmonized Light Vehicles (WLTP) homologation cycles [19]. Two engine load conditions were chosen, 2 and 5 bar of Brake Mean Effective Pressure (BMEP). The first represents low load conditions, the second one for being a critical condition about NOx and PM emissions. A previous study [18] was mainly devoted to evaluating the injection system performance with different working fluids and the engine-emissions adopting a conventional calibration without EGR. In this work, the investigation was aimed at an in-depth study on the combustion process mainly at part load, $2000 \times 2$, where problems related to the complete oxidation of the fuel could occur, and $2000 \times 5$ to evaluate the significant reduction of particulate emissions due to presence of LPG in the mixture. Both tested points were performed at a constant engine-out NOx level, varying the EGR rate.

Table 2. Engine and spray parameters at different load conditions [18].

\begin{tabular}{|c|c|c|c|c|c|c|c|c|c|c|}
\hline \multirow{2}{*}{$\begin{array}{c}\text { Parameters } \\
{[\mathrm{rpm}] \times[\mathrm{bar}]}\end{array}$} & \multicolumn{7}{|c|}{ Engine } & \multicolumn{3}{|c|}{ Spray } \\
\hline & $\begin{array}{l}\text { IMEP } \\
\text { [bar] }\end{array}$ & $\begin{array}{c}p_{\text {rail }} \\
\text { [bar] }\end{array}$ & $\begin{array}{c}\text { CA50 } \\
\text { [CAD aTDC] }\end{array}$ & $\underset{\text { [barG] }}{p_{\text {int }}}$ & $\begin{array}{c}p_{\text {exh }} \\
\text { [barG] }\end{array}$ & $\begin{array}{l}\mathrm{T}_{\text {int }} \\
{[\mathrm{K}]}\end{array}$ & $\begin{array}{l}\text { NOx } \\
{[\text { ppm] }}\end{array}$ & $\begin{array}{l}T_{\text {ch }} \\
{[K]}\end{array}$ & $\begin{array}{c}\mathrm{p}_{\mathrm{ch}} \\
{[\text { bar] }}\end{array}$ & $\begin{array}{c}\text { ET } \\
{[\mathrm{ms}]}\end{array}$ \\
\hline $2000 \times 2$ & 4.1 & 750 & 10 & 0.11 & 0.32 & 339 & 60 & \multirow{2}{*}{$300-473$} & \multirow[b]{2}{*}{1} & \multirow{2}{*}{0.6} \\
\hline $2000 \times 5$ & 7.0 & 850 & 9 & 0.21 & 0.43 & 336 & 83 & & & \\
\hline
\end{tabular}


The additional study was concerned with the experimental characterization of the spray, under non-evaporative and evaporative conditions, to assess the atomization characteristics among diesel and mixed fuels. The spray evolution was characterized by high-speed shadowgraph imaging [21]. The optical layout is schematized in Figure 2. To objectively evaluate the spray evolution for liquid/vapour phases, a customized algorithm developed in MATLAB ${ }^{\circledR}$ [22] was employed, capable of defining the spray's macroscopic parameters, i.e., the spray tip penetration and cone angle. The spray penetration was calculated as the maximum axial distance of the jet contour from the injector tip. The cone angle, i.e., the angle of the cone enclosing the jet, was measured from a linear fit through the jet outer edges, where the origin is fixed at the injector tip.

The tests were carried out adopting the injection strategies used for the engine tests in terms of rail pressure and energizing time (ET) of pulses, while the combustion chamber conditions in terms of temperatures and back-pressures were not performed for the present work. Therefore, the rail pressures ( $\left.\mathrm{p}_{\text {rail }}\right)$ were set at 750 and 850 bar, at different chamber temperature $\left(\mathrm{T}_{\mathrm{ch}}\right) 300 \mathrm{~K}$ and $473 \mathrm{~K}\left(\mathrm{p}_{\mathrm{ch}} 1 \mathrm{bar}\right)$, and the energizing timing of $0.6 \mathrm{~ms}$. Five consecutive events were acquired for each injection condition to evaluate the mean value and the standard deviation. The injection conditions are summarized in Table 2.

\subsection{Fuel Characteristics}

LPG is a mixture of alkane hydrocarbons composed mainly of butane and propane. Table 3 shows the main thermodynamic properties of both fuels, indicating the properties of the mixtures obtained through linear interpolation. LPG is in the liquid state in a pressure range of 2-8 bar in ambient condition, while at $p=1$ bar at $298 \mathrm{~K}$ (standard conditions), it is in the gaseous state. Likewise, by increasing the LPG mass percentage, the LHV (Low-Heating Value) and the heat of vaporization of the blend increase [18]. The LPG impact in the diesel fuel, in terms of the combustion characteristics and emissions of the engine, was assessed by testing the following fuels:

1. Commercial Diesel EN590.

2. DLPG $20 \rightarrow 20 \% \mathrm{w} / \mathrm{w}$, L.P.G. in diesel.

3. DLPG35 $\rightarrow 35 \% \mathrm{w} / \mathrm{w}$, L.P.G. in diesel.

Table 3. Fuels proprieties [18].

\begin{tabular}{ccccc}
\hline Fuel Name & Diesel & DLPG20 & DLPG35 & LPG \\
\hline LPG content $w / w[\%]$ & 0 & 20 & 35 & 100 \\
Density (liquid state) $[\mathrm{kg} / \mathrm{m} 3]$ & 836 & 772 & 723 & 514 \\
Low-Heating Value $[\mathrm{MJ} / \mathrm{kg}]$ & 42.5 & 43.2 & 43.8 & 46.1 \\
Latent Heat of vaporization $[\mathrm{kJ} / \mathrm{kg}]$ & 260 & 294 & 320 & 430 \\
Stoichiometric A/F [-] & 14.67 & 15.4 & 15.6 & 16.7 \\
Boiling point $(0.1 \mathrm{MPa})\left[{ }^{\circ} \mathrm{C}\right]$ & 362 & - & - & -42 \\
Autoignition Temperature $\left[{ }^{\circ} \mathrm{C}\right]$ & 250 & - & - & $365-470$ \\
Cetane number & 56.2 & - & - & $<2$ \\
H/C [-] & 1.86 & 2.3 & 2.49 & 3.43 \\
\hline
\end{tabular}

Two different mixing levels of LPG in diesel were chosen. The choice of a blend with $20 \%$ is justified by the need to guarantee engine reliability, without significantly altering its characteristics. DLPG35 was chosen to assess, with a higher LPG level, its impact on combustion, performance, and emissions.

The fuel system was modified to ensure reliable operation based on the characteristics of the fuels. The system is a closed circuit at a pressure of about 8 bar, to guarantee fuel in the liquid state. The tank in which the mixture is prepared in the desired mass ratio can support pressures up to 20 bar. For more details of the injection system layout, refer to $[23,24]$. 


\section{Results}

The results section has been arranged into sub-sections. Firstly, the results of the experimental characterization of the spray are analyzed, highlighting the main differences compared to the reference diesel.

\subsection{Spray Characterization of Diesel/LPG Blends}

\subsubsection{Non-Evaporation Condition $\left(\mathrm{T}_{\mathrm{ch}}=300 \mathrm{~K}\right)$}

The spray tip evolution and cone angle against After the Start of Injection (ASOI) timing for diesel, DLPG20, and DLPG35 at different injection pressures ( $\mathrm{p}_{\text {rail }}$ ) are shown in Figure 3. All tested fuels behave similarly; the spray initially penetrates faster due to the low atomization in the first stage, after which it progressively slows down due to air entrainment and the decrease of the droplets' momentum [25]. This behaviour results from a lower momentum of the jet, due to the lower density of the blends than diesel [26], and from lower surface tension and viscosity, which guarantee greater atomization [27]. As injection pressure increases, the differences in spray penetration between the fuels decrease because of higher spray momentum and lower drag forces [28].
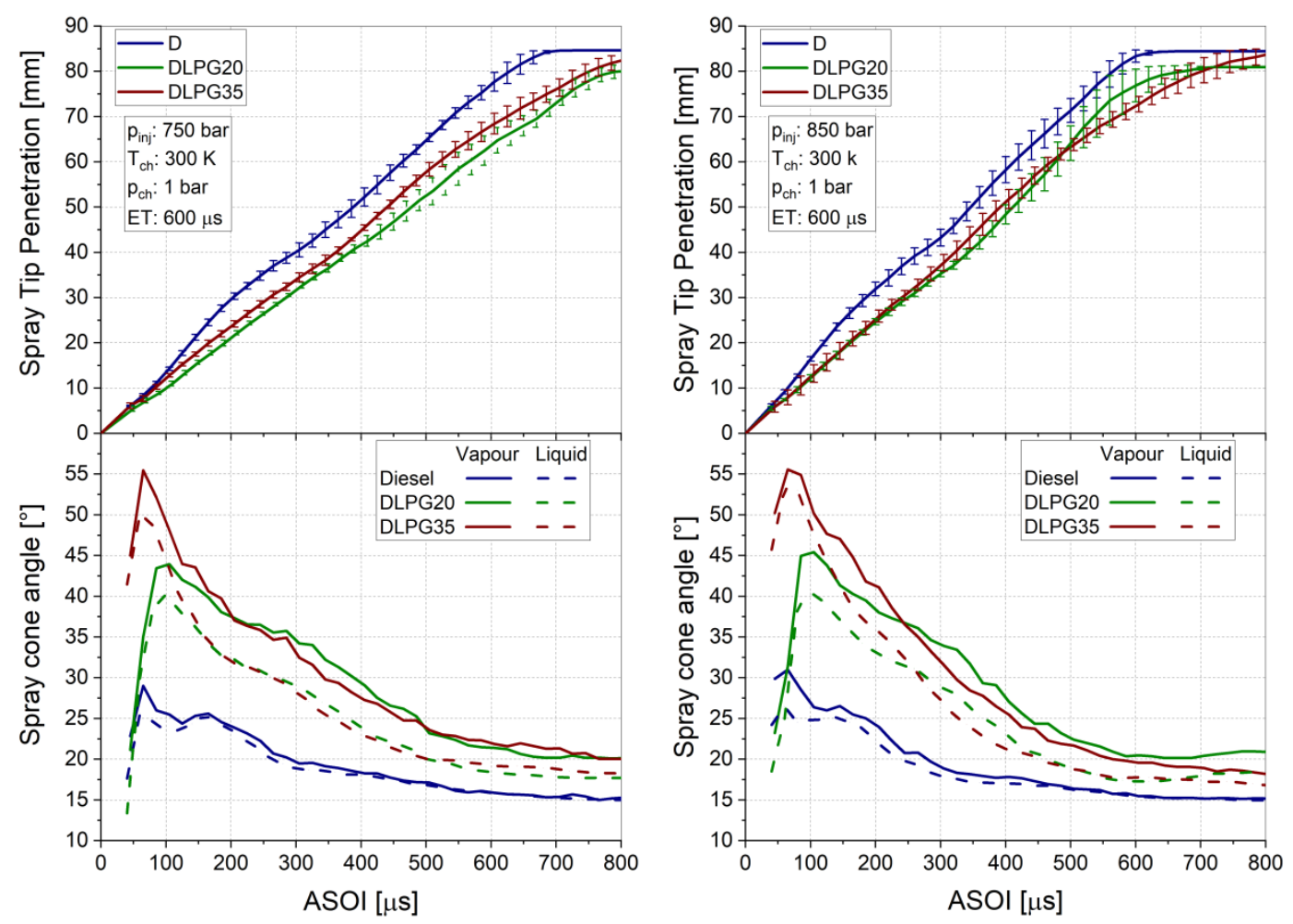

Figure 3. Spray characterization in terms of tip penetration and spray cone angle for different fuels under non-evaporation conditions $\left(\mathrm{T}_{\mathrm{ch}}=300 \mathrm{~K}\right)$.

Minor differences between the spray penetrations of the blends have been observed for both conditions.

The addition of LPG to diesel tends to proportionally increase the spray cone angle, due to the stronger turbulent flow interaction caused by a lower density and LPG vaporizing shortly after injection because of its low flash-boiling point [6]. The effect of LPG vaporization can be seen from the first stages of the injection event. Although varying the percentage of LPG in the steady-state injection phase, there are no differences in terms of spray diffusion for both the vapor and liquid phases. The standard deviation was omitted for graphic reasons but corresponded in a range of $2-4 \%$. Furthermore, a higher injection pressure does not involve significant variations for both parameters considered for DLPG blends, while for diesel an affect up to $400 \mu$ s is evident [29]. 


\subsubsection{Evaporation Condition $\left(\mathrm{T}_{\mathrm{ch}}=473 \mathrm{~K}\right)$}

Figure 4 shows a sample sequence of spray images for the different fuels under evaporative conditions, at a rail pressure of 750 bar. The red and blue lines indicate the boundaries of the vapor phase and the liquid phase, respectively. Figure 5 shows the time evolution, at different injection pressures, of spray penetration and cone angle for the tested fuels.

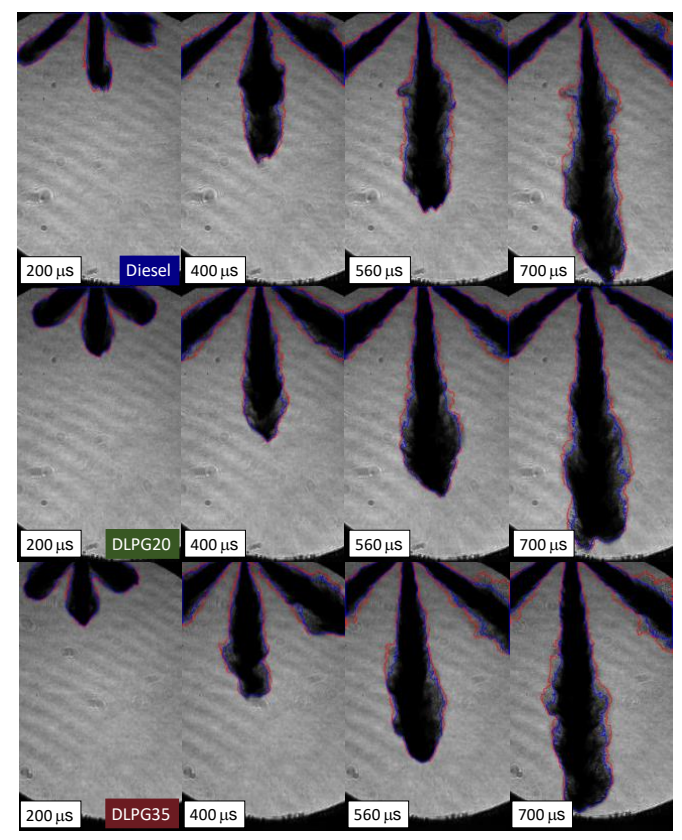

Figure 4. Spray sequence under evaporative conditions at rail pressure of 750 bar, liquid (blue), and vapor (red) detection for different fuels (diesel, DLPG20 and DLPG35).
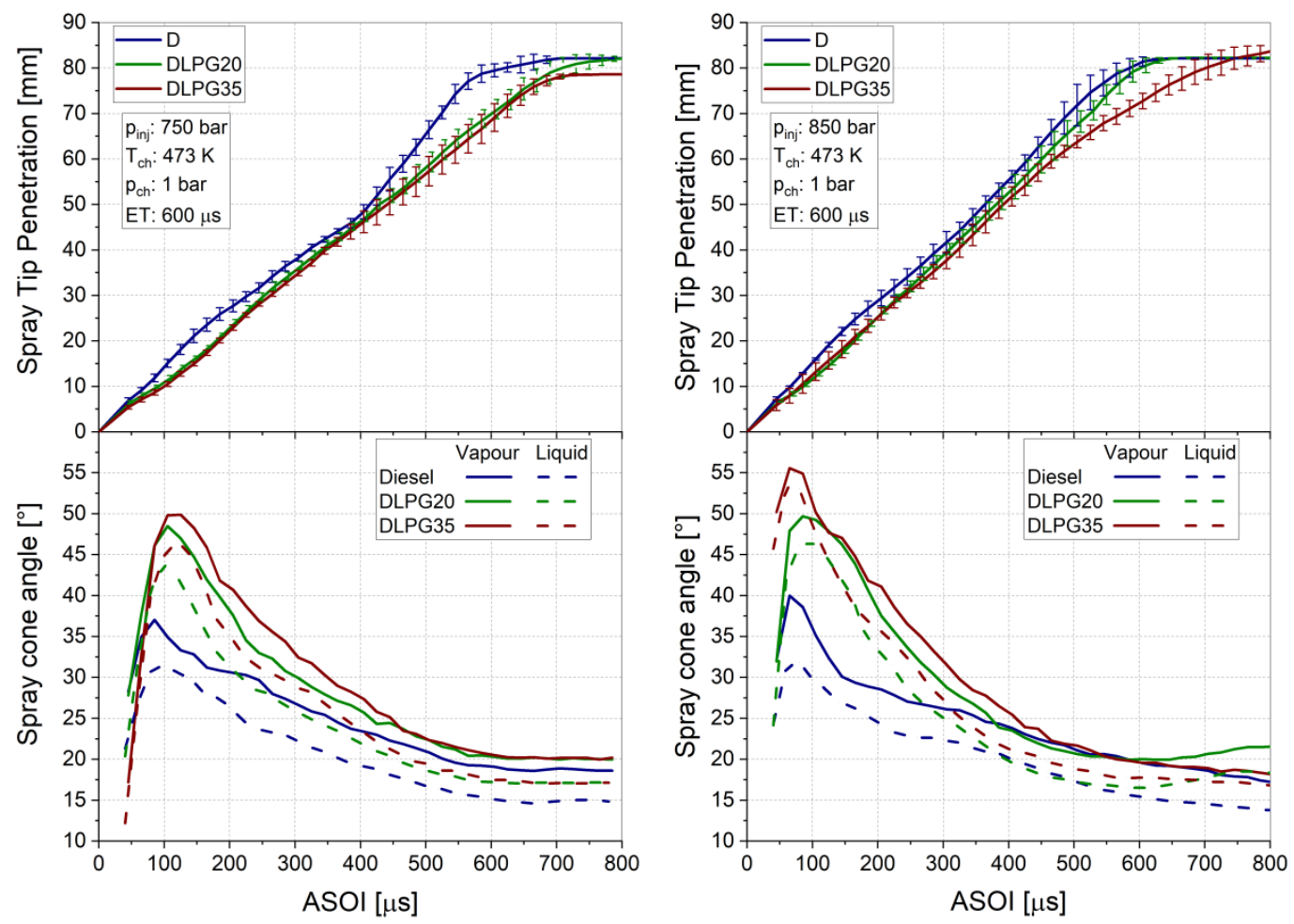

Figure 5. Spray characterization in terms of tip penetration and spray cone angle for different fuels under evaporating condition $\left(\mathrm{T}_{\mathrm{ch}}=473 \mathrm{~K}\right)$. 
As well as in non-evaporative conditions, diesel/LPG sprays penetrate less than pure diesel. However, due to the lower gas density, the differences are less marked than in non-evaporative conditions and are further reduced as rail pressure increases [27]. Figure 5 also shows the spray cone angle evolution in evaporating condition; it can be noted an increase of it, compared to diesel. This aspect is particularly evident also in Figure 4, at about $200 \mu \mathrm{s}$, a greater cone angle is observed for mixtures compared to diesel. It is due to the greater atomization, which further promotes the LPG vaporization. This affected the spray evolution in the steady-state phase, in particular at higher $p_{\text {rail }}$, causing a lesser spray cone angle because of the higher evaporating rate, evident after about $400 \mu$ s ASOI, when the angle is progressively reduced. Still, in non-evaporated conditions, it remains aligned on constant values. The increase in injection pressure, combined with the high temperature, unlike the non-evaporating case, also increases in spray penetration. Furthermore, a more significant difference is observed between the two blends, particularly on the penetration in the interval $450-700 \mu \mathrm{s}$.

\subsection{Combustion Analysis on SCE}

In this section, an LPG-diesel blend assessment in terms of combustion, performance and emissions compared to the diesel is reported, for two test points in a steady-state condition. The tests were performed adopting a conventional injection strategy characterized by a pilot plus main injection, using EGR. The injection phasing and the energizing time of the main pulse (ETmain) were controlled to set the combustion phasing (CA50) and IMEP (Indicated Mean Effective Pressure) at the targets equal to the reference calibration value as reported in Table 2. The other injection parameters, such as ET (energizing time) of pilot pulse, dwell time, prail (rail pressure), were kept constant. The calibration settings are reported in the Testing Methodology section. For both test points, the EGR rate was varied to achieve the NOx target (Table 2).

The comparison between the in-cylinder pressure $\left(p_{\text {cyl }}\right)$ and the HRR shows a forward shift of the peak firing pressure (pfp), due to the pilot combustion's ineffectiveness using LPG, and a corresponding increase of the maximum in-cylinder pressure. The combustion then moves from a diffusive mode, typical for diesel fuel, to a more premixed one, as evidenced by a reduced combustion duration [30]. The differences increase when increasing the LPG concentration. This can be ascribed to the high volatility of LPG and its very low cetane number, resulting in a lower auto-ignition tendency of the blends [6]. Different behaviour is observed with increasing the load. There is an increase in the HRR peak compared to diesel. This is probably due to even less effective pilot combustion than in the case of 2 bar of BMEP. It causes a further delay on the start of combustion (CA10), which is slightly delayed compared to diesel, as illustrated in Figure 6.

Indeed, to keep constant CA50, the injection phasing was significantly advanced; this aspect is even more relevant at low load, where the delta SOI is of about 5 deg for DLPG20 and $10 \mathrm{deg}$ for DLPG35, to the reference calibration.

For the low load condition, $2000 \times 2$ with DLPG35, the reference pilot quantity is insufficient to promote a stable premixed combustion phase due to the low-efficiency pilot combustion. Therefore, an increase of the pilot quantity at constant dwell-time was required (Figure 6) with an improvement in pilot combustion efficiency (comparable diesel pilot HR), and a reduction of the ignition delay (ID) and the combustion noise (Figure 7).

More compact combustion of LPG-diesel blends is observed compared to conventional diesel for the higher load (Figure 6, right), with the pilot combustion evolving entirely in the main combustion phase. This results in an advantage in terms of combustion duration and therefore, of thermodynamic efficiency. In this test point $(2000 \times 5)$, a pfp increase is observed, indicating a negligible LPG effect on the combustion process with a consequence influence on the combustion noise. Also, there is an increase in the HRR peak compared to diesel. This is probably due to even less efficiency of the pilot combustion than the 2 bar case. It causes a further delay of the start of combustion, which is slightly delayed compared to the diesel, as shown in Figure 6. 

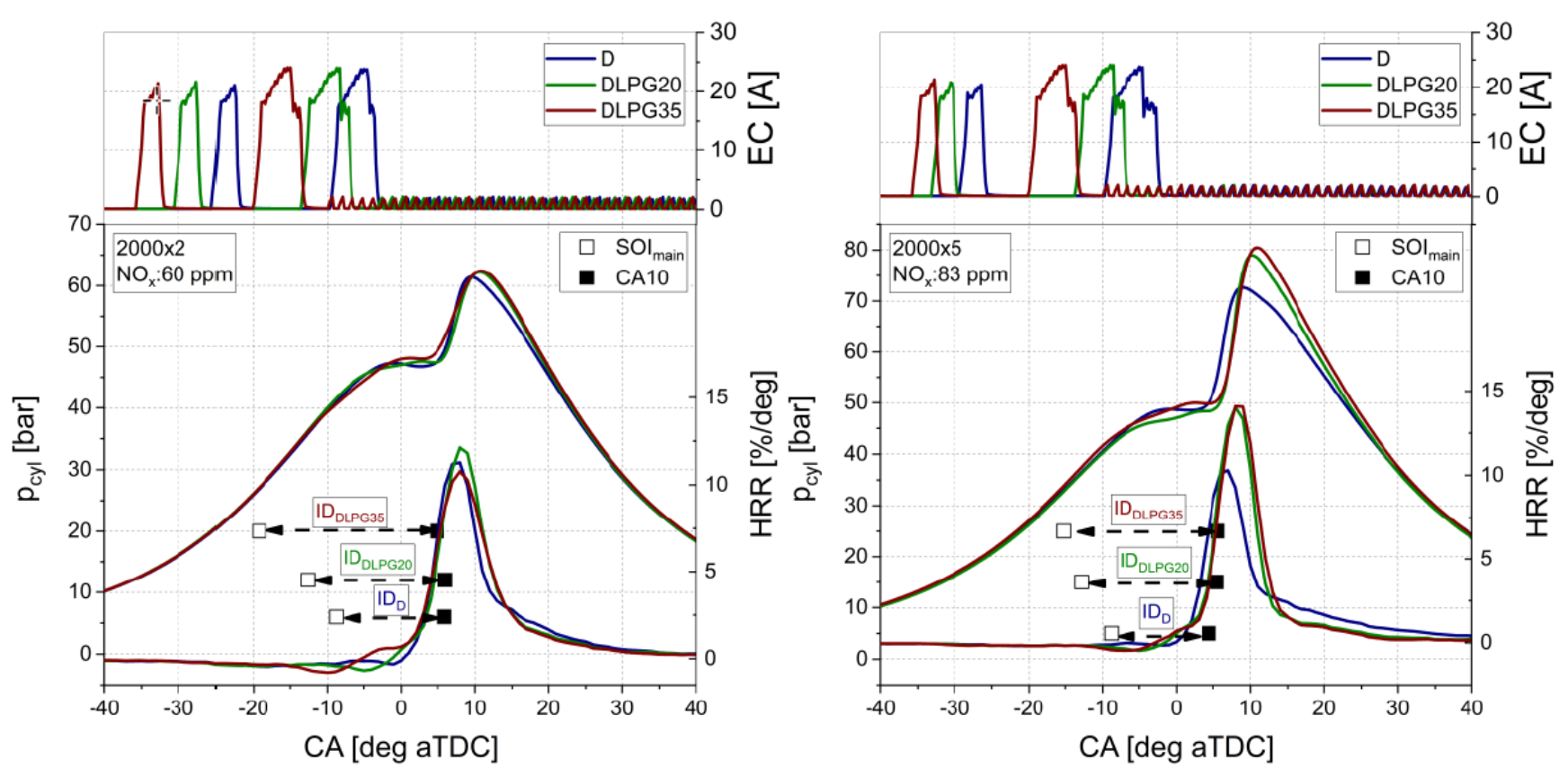

Figure 6. Pressure, HRR, Ignition Delay and injector energizing current at $2000 \times 2$ bar (left) and $2000 \times 5$ bar at constant NOx.
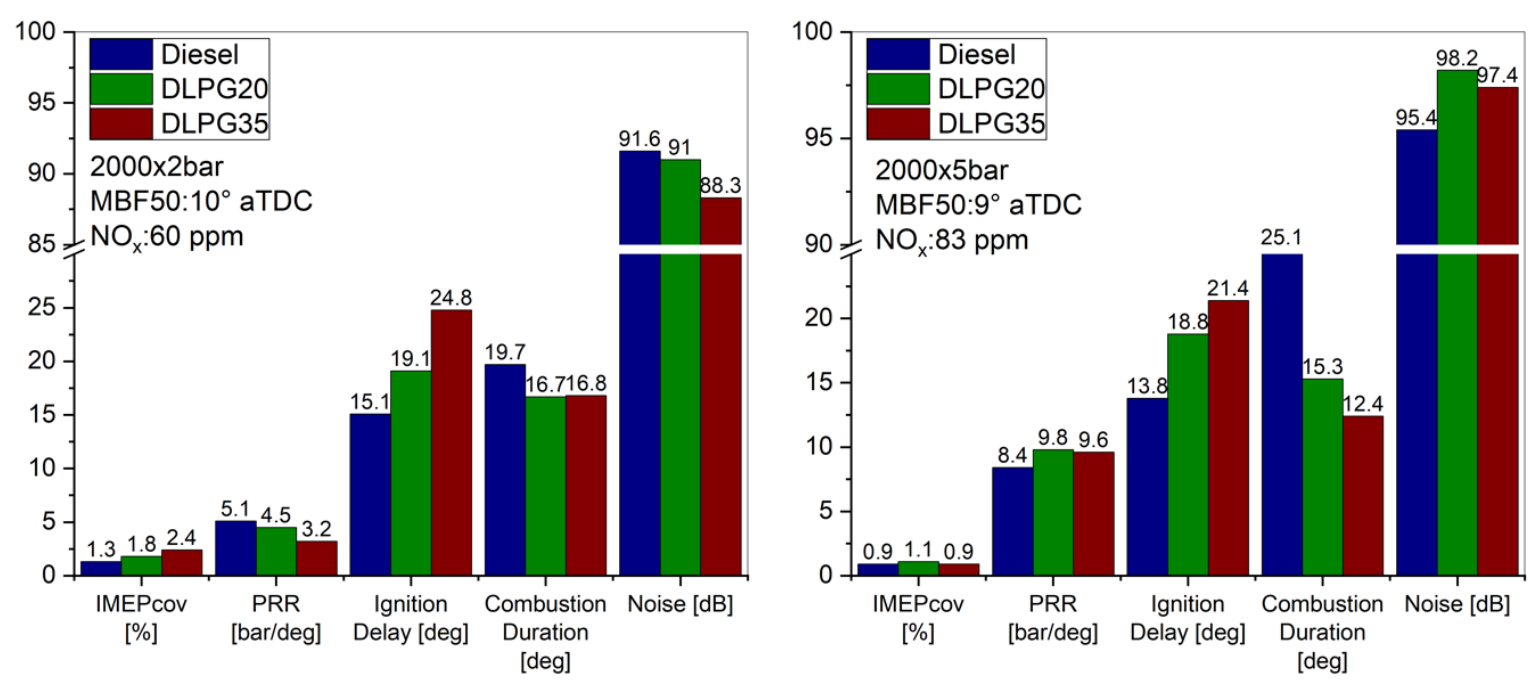

Figure 7. Combustion characteristics at $2000 \mathrm{r} / \mathrm{min}$ at different engine loads for different LPG-diesel blends compared to diesel.

In Figure 7, the ignition delay increases proportionally with the LPG mass fraction in the blended fuels due to the lower cetane number and increase of the LPG-Diesel evaporation heat. Figure 7 also provides the combustion duration at 2 and 5 bar BMEP for different fuels employed. It is reduced proportionally to the LPG mass ratio in the range 3-13 deg. Thanks to its characteristics, a longer ignition delay is observed, favoring an improved air-fuel mixing of about 5-9 deg for 2 bar of BMEP and 2-8 deg at higher load for DLPG20 DLPG35, respectively.

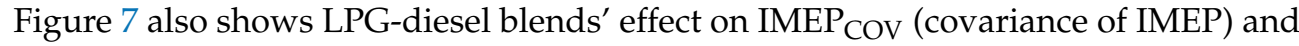
maximum pressure rise rate (PRR). The use of blends causes a slight PRR rise at a higher load (5 bar of BMEP) in acceptable ranges. However, at lower load, the pilot injection guarantees combustion noise attenuation, for DLPG35 of about $3.3 \mathrm{dBA}$. In contrast, in the 5 bar of load, the combustion noise reaches high values and over the imposed target of diesel one. Therefore, it will be necessary to recalibrate the injection pattern, particularly 
the ET pilot, to reduce it. Additionally, IMEP $\mathrm{COV}$ (cycle-to-cycle stability) for LPG blends does not introduce significant drift than diesel fuel.

In Figure 8, the efficiencies are represented as column bars for both tested points for different fuels. The equation used to calculate the global efficiency nfuel is reported below as Equation (1).

$$
\eta_{\text {fuel }}=\frac{1}{\text { ISFC } \cdot \mathrm{LHV}_{\mathrm{blend}}}=\eta_{\mathrm{comb}} \cdot \eta_{\text {thermal }}
$$
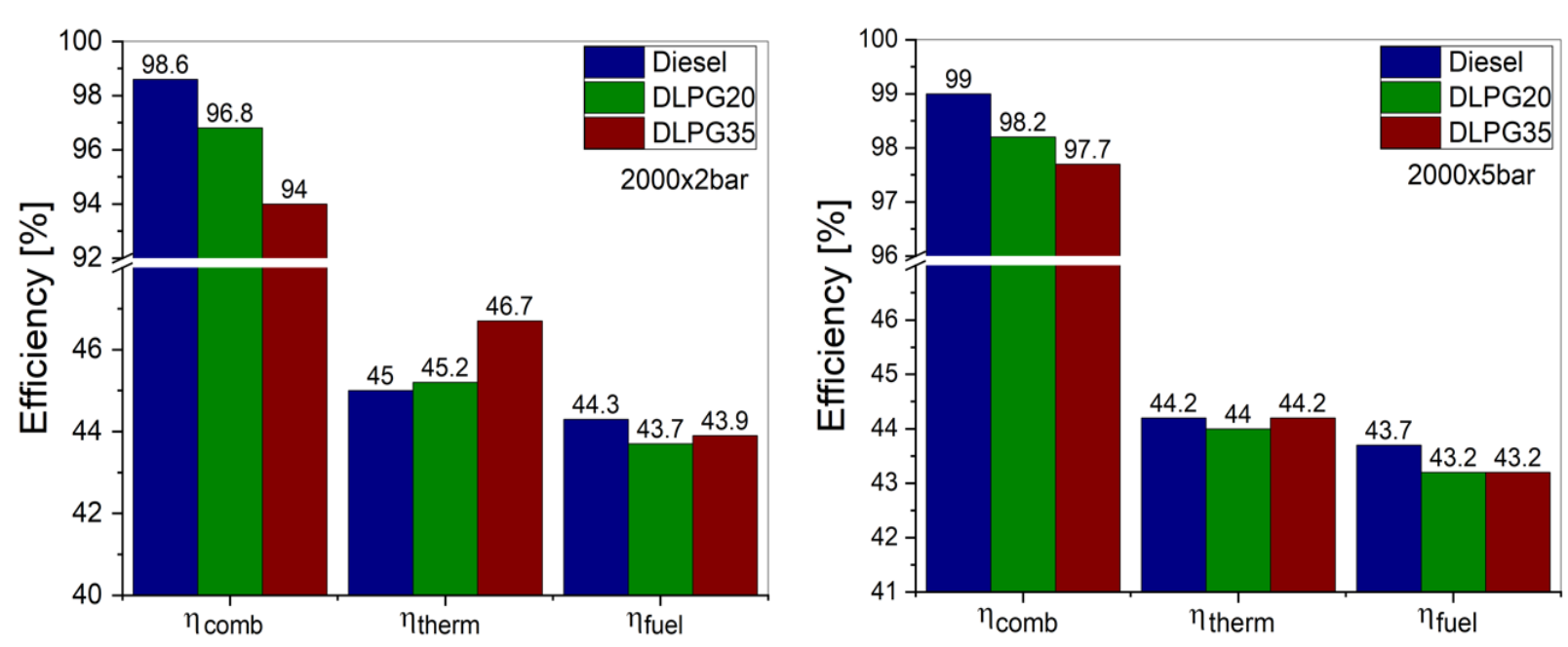

Figure 8. Efficiency parameters at $2000 \mathrm{rpm}$ at different engine loads for different LPG-diesel blends compared to diesel.

The use of blends does not involve significant variations in fuel conversion efficiency $\left(\eta_{\text {fuel }}\right)$, with a reduction in the range of 0.4-0.7 compared to diesel. Due to the lower combustion efficiency (see the HRR pilot combustion in Figure 6) because of overmixing conditions, it leads to over-lean regions $[23,24]$. The air-fuel equivalence ratio $(\lambda)$ values are reported in Table 4.

Table 4. Equivalence ratio $(\lambda)$ for different LPG-diesel blends compared to diesel.

\begin{tabular}{cccc}
\hline $\boldsymbol{\lambda}$ & D & DLPG20 & DLPG35 \\
\hline $2000 \times 2$ & 1.8 & 1.9 & 1.9 \\
$2000 \times 5$ & 1.2 & 1.3 & 1.4 \\
\hline
\end{tabular}

As the LPG fraction increases, a reduction in combustion efficiency is observed due to a lower overall equivalence ratio, as shown in Table 4. In fact, because of a higher ignition delay (a lower heat of vaporization and cetane number), a greater fuel mass is trapped in the crevices volumes compared to diesel combustion, justifying this efficiency reduction [31,32]. This fuel mass, not participating in the combustion process, is emitted as $\mathrm{CO}$ and THC emissions, which contribute to this reduction. Regarding thermal efficiency, $\eta_{\text {therm }}$, the trend is not clear, considering that it is also a function of the discharge temperature. At $2000 \times 2$, a rise of $\eta_{\text {therm }}$, proportional to the LPG mass ratio, can be noted, but this aspect is not evident for the higher load. It is probably caused by the LPG evaporation, which reduces the temperature in the combustion chamber [33], as well as, with the reduction of the combustion duration, there is less time for heat transfer losses. The $\eta_{\text {therm }}$ is almost constant for all tested fuels and even slightly reduced with DLPG20. The ISFC trend (Figure 9) confirms what is shown in Figure 8 regarding the thermodynamic efficiency. A reduction of about $1 \%$ is observed for DPLG35, while DPLG20 and diesel values are aligned. As already highlighted above, a shorter CA90-10 (combustion duration) and a better fuel distribution justify these improvements [34,35]. 

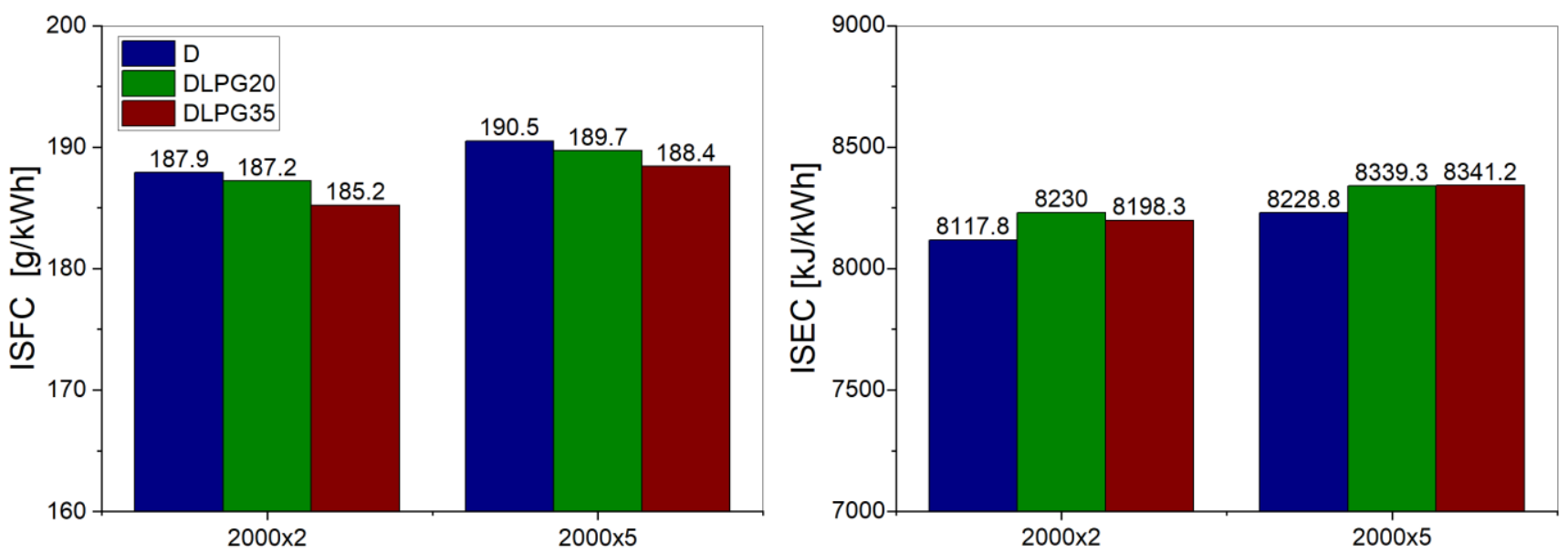

Figure 9. ISFC and ISEC parameters at $2000 \mathrm{r} / \mathrm{min}$ and different engine loads for the three blends.

Figure 9 also shows the ISEC (indicated specific energy consumption), obtained by multiplying the ISFC and the fuel's energy density. The results confirmed what is highlighted for ISFC. The use of blends guarantees fuel saving in the same operating condition for the test points considered.

Figure 10 illustrates the gaseous emissions in terms of $\mathrm{NOx}, \mathrm{THC}, \mathrm{CO}, \mathrm{PM}$ and $\mathrm{CO}_{2}$ in specific quantities for both test points considered. A notable reduction in soot is the main effect resulting from the use of LPG-diesel blends [7]. The fuel with the highest LPG mass ratio, DLPG35, clearly shows the most significant reduction of about 1.2 and $5.6 \mathrm{~g} / \mathrm{kWh}$ for 2 and 5 bar of BMEP, respectively. As is well known from the literature, the soot is formed in locally rich regions; therefore, this new blend allows to improve the air-fuel mixing and guarantee such a significant reduction. This trend is also confirmed by the equivalence ratio, reported in Table 4. There is an increase in THC emissions proportional to the LPG amount. It is typical of combustion characterized by high ignition delays. This leads to a greater fuel mass trapped in the crevices volumes, as discussed previously, and an excessive mixing, creating very lean-regions, thus not guaranteeing complete combustion due to low temperatures and increasing in unburnt emissions [36].
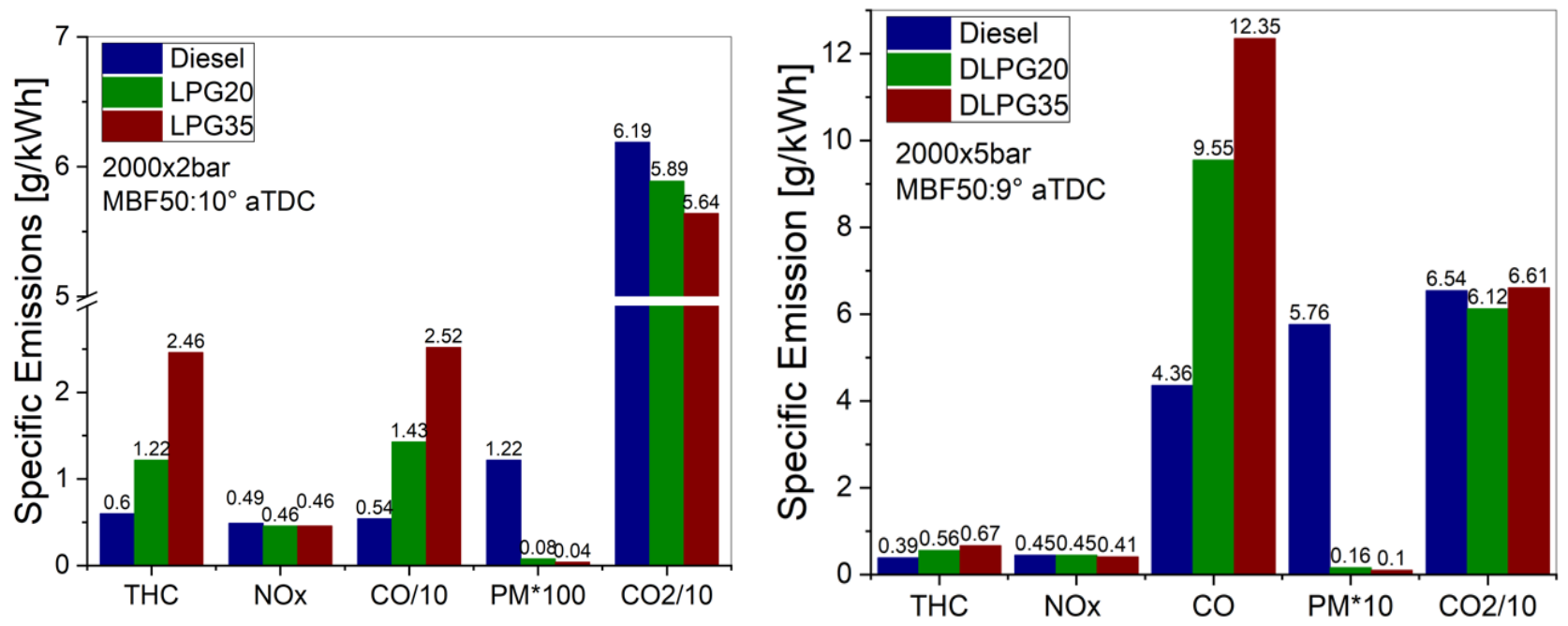

Figure 10. Emissions parameters at $2000 \mathrm{r} / \mathrm{min}$ and different engine loads for the three blends.

The increase in THC is reduced at higher loads, as the in-cylinder temperature and pressure are high enough to minimize the overmixing effect, favoring combustion efficiency more. 
As well as THC emissions, $\mathrm{CO}$ emissions also increase for LPG-diesel blends compared to the diesel fuel, as shown in Figure 10. A significant increase is observed between the tested fuels, with a notable increase in the LPG percentage function. As already mentioned previously, this raise is due to more premixed combustion leading to an increase in unburnt emissions, and it is inversely proportional to the load. A reduction in $\mathrm{CO}_{2}$ emissions is observed thanks to the higher $\mathrm{H} / \mathrm{C}$ ratio and despite the lower $\eta_{\text {comb }}$. The difference is significant at $2000 \times 2$ tested point, with a reduction of $4 \%$ and 9\% for DLPG20 and DLPG35 respectively, while at the highest load (5 bar BMEP) the values are aligned.

The excellent results obtained with the use of the LPG-Diesel blends in a CI engine, in terms of polluting emissions and performance, encourage future activities about the optimization of engine control strategies and exhaust gas after-treatment systems.

\section{Conclusions}

An assessment of the new fuel concept application, LPG-diesel, was performed through a spray characterization and tests on a CI single-cylinder engine. The characterization was carried out by adopting different LPG mass percentages in diesel fuel in the ratio 20:80 and 35:65. The experimental results were divided into two paragraphs: optical characterization of the spray in the different injection conditions and the combustion analysis in terms of engine performance and gaseous emissions employing the blends. The results were compared to diesel fuel.

About the spray characterization, the LPG effect compared to diesel reduces the tip penetration and favors the opening of the spray cone angle for both conditions tested. This difference in terms of penetration decreases with rail pressure and chamber temperature. This behaviour is also confirmed in evaporating conditions, thanks to greater volatility of the LPG. This reduction could be compensated by a higher injection pressure which, adopting the LPG-diesel mixture, could guarantee a high level of atomization and airfuel mixing.

The combustion characterization was performed on a single-cylinder $\mathrm{CI}$ engine fueled with a different LPG-Diesel mixture. The results show what was already emerged in the spray characterization, the high atomization and the increase in the ignition delay favor the premixed combustion. As demonstrated by the increased cone angle, the higher evaporation rate and the faster atomization allow reducing soot emissions (about 95\%) at equal NOx target and by improving the efficiency, in particular at higher loads.

A benefit in terms of the indicated specific fuel consumption is observed compared to diesel, proportional to the LPG mass ratio, for DLPG35, of about 1\%, while DPLG20 values are aligned. The improvement is due to the better fuel distribution in the combustion chamber and a reduction in the combustion duration and fewer heat losses. However, these aspects negatively contribute to increase ignition delay in the range 2-9 deg depends on the load and the LPG percentage, causing an overmixing leading to a significant increase in unburned gas emissions, $\mathrm{CO}$ and $\mathrm{HC}$.

It should be noted that the tests carried out did not aim to optimize the calibration of engine parameters with the new fuels but were intended to compare the results (in terms of emissions and performance) with traditional fuel.

In conclusion, the results obtained are very comforting as with LPG-Diesel mixtures there is very low production of pollutants (in particular PM) during combustion, which allows, once the calibration has been optimized (injection strategies, EGR, etc.), to improve the performance of the overall vehicle after-treatment systems. The greater quantity of $\mathrm{CO}$ and THC emission can be easily converted in the oxidant catalyst. Simultaneously, the reduced amount of PM produced can be filtered much more efficiently in the particulate filters (the number of regenerations events of DPF is considerably reduced). Furthermore, it is possible to redesign the after-treatment system by reducing its size and weight. Finally, the use of EGR can also be optimized, allowing an improvement in engine performance. 
Author Contributions: Data curation, R.I.; investigation, R.I., R.M. and M.L.; methodology, G.D.B.; supervision, M.C.; writing - original draft, R.M. All authors have read and agreed to the published version of the manuscript.

Funding: This research received no external funding.

Institutional Review Board Statement: Not applicable.

Informed Consent Statement: Not applicable.

Data Availability Statement: The data presented in this study are available on request from the corresponding author. The data are not pubblicly available because we are studying and developing two innovative solutions that will be patented.

Acknowledgments: The authors are grateful to C. Rossi, B. Sgammato, R. Maniscalco and A. Schiavone for technical support.

Conflicts of Interest: The authors declare no conflict of interest.

\section{Definitions/Abbreviations}

ASOI

BMEP

CA

After Start of Injection

CA10

CA50

CA90-10

CI

$\mathrm{CO}$

$\mathrm{CO}_{2}$

cyl

deg

DLPG

EC

EGR

ET

ET

HC

HRR

ID

IMEP

IMEP $_{\mathrm{COV}}$

ISEC

ISFC

is $X$

LHV

LPG

$\mathrm{NO}_{x}$

$\mathrm{p}_{\mathrm{ch}}$

$\mathrm{P}_{\text {cyl }}$

pexh

$p_{\text {int }}$

PM

prail

PRR

Q

SCE

SOI

$\mathrm{T}_{\mathrm{ch}}$

TDC

$\eta_{\text {comb }}$

$\eta_{\text {fuel }}$

$\eta_{\text {thermal }}$

Brake Mean Effective Pressure

Crank Angle Degrees

10\% Mass Burning Fraction

50\% Mass Burning Fraction

Combustion Duration

Compression Ignition

Carbon Monoxide

Carbon Dioxide

cylinder

degree

Diesel-LPG blend

Energizing Current

Exhaust Gas Recirculation

Energizing Time

Energizing Time

Hydrocarbons

Heat Release Rate

Ignition delay (SOI-CA10)

Indicated Mean Effective Pressure

Covariance of IMEP

Indicated Specific Energy Consumption

Indicated Specific Fuel Consumption

Indicated Specific Emissions

Lower Heating Value

Liquefied Petroleum Gas

Nitrogen Oxide

Chamber pressure

In-Cylinder Pressure

Back-pressure

Boost Pressure

Particulate Matter

Rail Pressure

Pressure Rise Rate

Injected amount

Single-Cylinder Engine

Start of Injection

Chamber temperature

Top Dead Centre

Combustion efficiency

Global efficiency

Thermal efficiency 


\section{References}

1. Belgiorno, G.; Boscolo, A.; Dileo, G.; Numidi, F.; Pesce, F.C.; Vassallo, A.; Ianniello, R.; Beatrice, C.; Di Blasio, G. Experimental Study of Additive-Manufacturing-Enabled Innovative Diesel Combustion Bowl Features for Achieving Ultra-Low Emissions and High Efficiency. In SAE Technical Paper Series; SAE International: Warrendale, PA, USA, 2020.

2. Steinparzer, F.; Nefischer, P.; Stütz, W.; Hiemesch, D.; Kaufmann, M. The New BMW Six-Cylinder Top Engine With Innovative Turbocharging Concept, 37th ed.; Vienna Motoren Symposium: Wien, Austria, 2016.

3. Di Blasio, G.; Beatrice, C.; Ianniello, R.; Pesce, F.C.; Vassallo, A.; Belgiorno, G.; Avolio, G. Balancing Hydraulic Flow and Fuel Injection Parameters for Low-Emission and High-Efficiency Automotive Diesel Engines. In SAE Technical Paper Series; SAE International: Warrendale, PA, USA, 2019. [CrossRef]

4. Di Blasio, G.; Beatrice, C.; Belgiorno, G.; Pesce, F.C.; Vassallo, A. Functional Requirements to Exceed the 100 kW/1 Milestone for High Power Density Automotive Diesel Engines. SAE Int. J. Engines 2017, 10, 2342-2353. [CrossRef]

5. Gill, S.; Tsolakis, A.; Dearn, K.; Rodríguez-Fernández, J. Combustion characteristics and emissions of Fischer-Tropsch diesel fuels in IC engines. Prog. Energy Combust. Sci. 2011, 37, 503-523. [CrossRef]

6. Lee, S.W.; Cho, Y.S.; Choi, W.C.; Lee, J.H.; Park, Y.J. Combustion characteristics of LPG and biodiesel mixed fuel in two blending ratios under compression ignition in a constant volume chamber. Int. J. Automot. Technol. 2012, 13, 1149-1157. [CrossRef]

7. Qi, D.; Bian, Y.; Ma, Z.; Zhang, C.; Liu, S. Combustion and exhaust emission characteristics of a compression ignition engine using liquefied petroleum gas-Diesel blended fuel. Energy Convers. Manag. 2007, 48, 500-509. [CrossRef]

8. Donghui, Q.; Longbao, Z.; Shenghua, L. Experimental studies on the combustion characteristics and performance of a naturally aspirated, direct injection engine fuelled with a liquid petroleum gas/diesel blend. Proc. Inst. Mech. Eng. Part D: J. Automob. Eng. 2005, 219, 253-261. [CrossRef]

9. Cao, J.; Bian, Y.; Qi, D.; Cheng, Q.; Wu, T. Comparative investigation of diesel and mixed liquefied petroleum gas/diesel injection engines. Proc. Inst. Mech. Eng. Part D: J. Automob. Eng. 2004, 218, 557-565. [CrossRef]

10. Beatrice, C.; Denbratt, I.; Di Blasio, G.; Di Luca, G.; Ianniello, R.; Saccullo, M. Experimental Assessment on Exploiting Low Carbon Ethanol Fuel in a Light-Duty Dual-Fuel Compression Ignition Engine. Appl. Sci. 2020, 10, 7182. [CrossRef]

11. Cao, J. On the Theoretical Prediction of Fuel Droplet Size Distribution in Nonreactive Diesel Sprays. J. Fluids Eng. 2001, 124, 182-185. [CrossRef]

12. Ma, Z.; Huang, Z.; Li, C.; Wang, A.X.; Miao, H. Effects of Fuel Injection Timing on Combustion and Emission Characteristics of a Diesel Engine Fueled with Diesel-Propane Blends. Energy Fuels 2007, 21, 1504-1510. [CrossRef]

13. Ma, Z.; Huang, Z.; Li, C.; Wang, X.; Miao, H. Combustion and emission characteristics of a diesel engine fuelled with dieselpropane blends. Fuel 2008, 87, 1711-1717. [CrossRef]

14. Pirouzpanah, V.; Kashani, B.O. Prediction of Major Pollutants Emission in Direct—Injection Dual—Fuel Diesel and Natural—Gas Engines. In SAE Technical Paper Series; SAE International: Warrendale, PA, USA, 1999. [CrossRef]

15. Papagiannakis, R.; Hountalas, D.T. Experimental investigation concerning the effect of natural gas percentage on performance and emissions of a DI dual fuel diesel engine. Appl. Therm. Eng. 2003, 23, 353-365. [CrossRef]

16. Myung, C.L.; Lee, H.; Choi, K.; Lee, Y.J.; Park, S. Effects of gasoline, diesel, LPG, and low-carbon fuels and various certification modes on nanoparticle emission characteristics in light-duty vehicles. Int. J. Automot. Technol. 2009, 10, 537-544. [CrossRef]

17. Cardone, M.; Mancaruso, E.; Marialto, R.; Sequino, L.; Vaglieco, B.M. Characterization of Combustion and Emissions of a Propane-Diesel Blend in a Research Diesel Engine. In SAE Technical Paper Series; SAE International: Warrendale, PA, USA, 2016.

18. Marialto, R.; Sequino, L.; Di Blasio, G.; Cardone, M.; Beatrice, C.; Ianniello, R.; Fontana, G. Combustion and Emission Characteristics of a Diesel Engine Fuelled with Diesel-LPG Blends. In SAE Technical Paper Series; SAE International: Warrendale, PA, USA, 2019. [CrossRef]

19. Di Blasio, G.; Belgiorno, G.; Beatrice, C. Effects on performances, emissions and particle size distributions of a dual fuel (methane-diesel) light-duty engine varying the compression ratio. Appl. Energy 2017, 204, 726-740. [CrossRef]

20. Heywood, J.B. Internal Combustion Engine Fundamentals; McGraw-Hill: New York, NY, USA, 1988.

21. Klein-Douwel, R.R.; Frijters, P.P.; Somers, L.; De Boer, W.W.; Baert, R.R. Macroscopic diesel fuel spray shadowgraphy using high speed digital imaging in a high pressure cell. Fuel 2007, 86, 1994-2007. [CrossRef]

22. Lazzaro, M.; Ianniello, R. Image processing of vaporizing GDI sprays: A new curvature-based approach. Meas. Sci. Technol. 2017, 29, 015402. [CrossRef]

23. Dijkstra, R.; Di Blasio, G.; Boot, M.; Beatrice, C.; Bertoli, C. Assessment of the Effect of Low Cetane Number Fuels on a Light Duty CI Engine: Preliminary Experimental Characterization in PCCI Operating Condition. In SAE Technical Paper Series; SAE International: Warrendale, PA, USA, 2011. [CrossRef]

24. Litzinger, T.; Stoner, M.; Hess, H.; Boehman, A. Effects of oxygenated blending compounds on emissions from a turbocharged direct injection diesel engine. Int. J. Engine Res. 2000, 1, 57-70. [CrossRef]

25. Park, S.H.; Kim, H.J.; Suh, H.K.; Lee, C.S. Atomisation and spray characteristics of bioethanol and bioethanol blended gasoline fuel injected through a direct injection gasoline injector. Int. J. Heat Fluid Flow 2009, 30, 1183-1192. [CrossRef]

26. Ma, Y.; Huang, S.; Huang, R.; Zhang, Y.; Xu, S. Spray and evaporation characteristics of n-pentanol-diesel blends in a constant volume chamber. Energy Convers. Manag. 2016, 130, 240-251. [CrossRef]

27. Kim, K.; Kim, D.; Jung, Y.; Bae, C. Spray and combustion characteristics of gasoline and diesel in a direct injection compression ignition engine. Fuel 2013, 109, 616-626. [CrossRef] 
28. Yu, W.; Yang, W.; Mohan, B.; Tay, K.L.; Zhao, F. Macroscopic spray characteristics of wide distillation fuel (WDF). Appl. Energy 2017, 185, 1372-1382. [CrossRef]

29. Wang, X.; Huang, Z.; Kuti, O.A.; Zhang, W.; Nishida, K. Experimental and analytical study on biodiesel and diesel spray characteristics under ultra-high injection pressure. Int. J. Heat Fluid Flow 2010, 31, 659-666. [CrossRef]

30. An, Y.; Jaasim, M.; Ali, M.; Vallinayagam, R.; Vedharaj, S.; Perez, F.H.; Sim, J.; Chang, J.; Im, H.; Johansson, B. Investigation of Premixed and Diffusion Flames in PPC and CI Combustion Modes (No. 2018-01-0899). In SAE Technical Paper Series; SAE International: Warrendale, PA, USA, 2018. [CrossRef]

31. Li, C.; Yin, L.; Shamun, S.; Tuner, M.; Johansson, B.; Solsjo, R.; Bai, X.S. Transition from HCCI to PPC: The Sensitivity of Combustion Phasing to the Intake Temperature and the Injection Timing with and without EGR. In SAE Technical Paper Series; SAE International: Warrendale, PA, USA, 2016.

32. Johansson, B. Förbränningsmotorer, Division of Combustion Engines; LTH Sweden: Lund, Sweden, 2006.

33. Al-Hassan, M. Effect of ethanol-unleaded gasoline blends on engine performance and exhaust emission. Energy Convers. Manag. 2003, 44, 1547-1561. [CrossRef]

34. Beatrice, C.; Di Blasio, G.; Pesce, F.C.; Vassallo, A.; Avolio, G.; Ianniello, R. Key Fuel Injection System Features for Efficiency Improvement in Future Diesel Passenger Cars. SAE Tech. Pap. Ser. 2019, 1, 1084-1099. [CrossRef]

35. Diwakar, R.; Domenech-Llopis, V. Physics of Combustion Noise Reduction with Multiple Injections in a DI Diesel Engine-A Computational Study. In SAE Technical Paper Series; SAE International: Warrendale, PA, USA, 2017.

36. Koci, C.P.; Fitzgerald, R.P.; Ikonomou, V.; Sun, K. The effects of fuel-air mixing and injector dribble on diesel unburned hydrocarbon emissions. Int. J. Engine Res. 2019, 20, 105-127. [CrossRef] 